\title{
DRUGS and the
}

Limits of Liberalism 



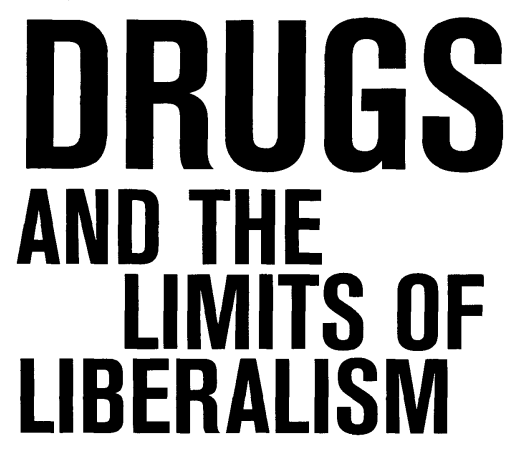

MORAL AND LEGAL ISSUES

Eөre oy Pablo De Greiff

CORNELL UNIVERSITY PRESS

ITHACA AND LONDON 
Copyright (C) 1999 by Cornell University

All rights reserved. Except for brief quotations in a review, this book, or parts thereof, must not be reproduced in any form without permission in writing from the publisher. For information, address Cornell University Press, Sage House, 512 East State Street, Ithaca, New York 14850.

First published 1999 by Cornell University Press.

Printed in the United States of America

Library of Congress Cataloging-in-Publication Data

Drugs and the limits of liberalism : moral and legal issues I edited by Pablo De Greiff.

p. cm.

Includes bibliographical references and index.

ISBN 0-8014-3561-7 (cloth : alk. paper)

1. Drug abuse-United States-Prevention. 2. Drug abuse-Moral and ethical aspects. 3. Liberalism-Moral and ethical aspects. 4. Drug abuseGovernment policy-United States. I. De Greiff, Pablo:

HV5825.D812 1998

$362.29^{\prime} 17^{\prime} 0973-d c 21$

98-48115

Cornell University Press strives to use environmentally responsible suppliers and materials to the fullest extent possible in the publishing of its books. Such materials include vegetable-based, low-VOC inks and acid-free papers that are recycled, totally chlorine-free, or partly composed of nonwood fibers.

$\begin{array}{llllllllllll}\text { Cloth printing } & 10 & 9 & 8 & 7 & 6 & 5 & 4 & 3 & 2 & 1\end{array}$ 